\title{
Collaborative Nexus Between University-Industry- Government as an Innovation for Community Development
}

\author{
Amni Zarkasyi Rahman ${ }^{1}$, Fendy Eko Wahyudi², Widiartanto ${ }^{3}$ \\ \{amni.rahman@live.undip.ac.id ${ }^{1}, \underline{\text { f.e.wahyudi@gmail.com }}{ }^{2}, \underline{\text { fafanabil@gmail.com }}^{3}$ \}
}

Universitas Diponegoro

\begin{abstract}
The relationship between university-government-industry will be able to give a significant impact in the effort of community empowerment in a region. This relationship cannot be separated from the importance of assistance done by the academia, government as framework and programs basis in refer to RPJMD (Mid-term Regional Development Plans), as well as funding from private sector through CSR for example. Road Map of empowerment which is the result of discussions and agreement between university-government-industry is necessary for the output of community development programs implemented in accordance with predetermined plans. This paper will provide a case study of collaborative nexus between academia, business private sectors, government in enhancing community development for people empowerment in Indonesia. By studying the case of community development project in Cilacap Central Java this paper seeks to portray the growing of CSR practice in developing countries. This paper argues that the strong collaboration and accordance between academia, private sector, and government are defining variable for applicable community development project. On the other hand, active role of community itself is critical for assuring community development programs able to achieve empowerment of the society.
\end{abstract}

Keywords: Relationship, Empowerment, CSR

\section{Introduction}

Innovation is a vital issue in every Indonesian's development planning, which is marked by the regulation that controls regional innovation systems [1]. The impact of the implementation of this innovation core is each region struggles to improve competitiveness, through the inter-regional cooperation, as well as through collaboration between governmentuniversities. Until now, there have been many initiations of the inter-regional cooperation and collaboration between government-universities as part of social innovation in community empowerment. However, not all them have done well [2]. One of the challenges that has implications for the successes of the community empowerment program is the preparation of the program's strategic plan through community participation.

The preparation of this strategic plan needs to pay attention to the main program, which later will become the main determinant of all empowerment programs, both in the direction of program policies, as well as program achievement strategies. However, the first thing to do is to identify policies that are sensitive to empowerment programs to avoid overlapping policies.

Furthermore, a preliminary survey is needed by applying the Rapid Rural Appraisal (RRA) and Participatory Rural Appraisal (PRA) methods [3] to determine empowerment 
programs that are "needed" by the community, not programs that are "desired" by the community.

\section{Methodology}

University-Industrial-Government collaboration as an innovation for community empowerment must be comprehensively understood through scientific thinking as a significant problem. Therefore, this research used descriptive qualitative method aimed to describe clearly the problem of research on the potential for collaboration and the implications for the success of community empowerment in Indonesia [4]. Furthermore, the potential for collaboration will be more seen through the ideal role of universities and industry in carrying out community empowerment processes. Also, the data is collected through literature studies [5] such as relevant scientific journals [6], online media, and official news portals.

This research also highly indebts with support from PT. Pertamina as one of Indonesia State owned Enterprise who is practicing their community development activities through collaborating with university. Thus, we can use this case study as the main case for portraying collaboration between state, private sectors and university.

\section{Result}

\subsection{Collaboration as the initial of empowerment}

Community empowerment is the main requirement in development planning, with the involvement of various stakeholders. One of the stakeholders of community empowerment is the university through community service activities that are part of the Tri Dharma Perguruan Tinggi. However, it is still rare for community service to collaborate with industry and government. Though this collaboration pattern is a triple helix concept that can improve the success of community empowerment programs [7]

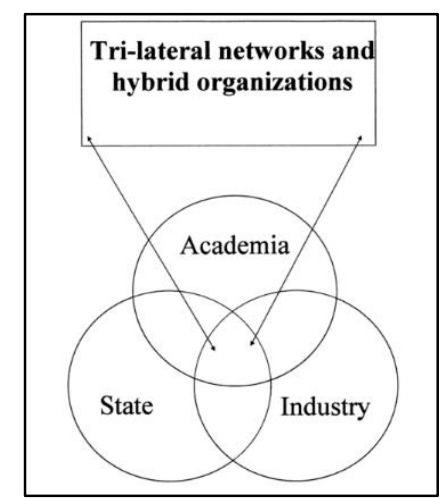

Fig. 1. The Triple Helix Relationship of University-Industry-Government [7]

In this case study, collaboration that has been carried out was education and training efforts for coastal communities in realizing business incubators in Tambakreja Urban Village, Cilacap Regency. This collaboration involved Univeristas Diponegoro-PT Pertamina TBBM Cilacap- Tambakreja Urban Village with the output of the formation of UKM (small medium 
enterprise) holding of food products processed by fisheries. This $U K M$ holding is a hybrid organization that can increase the income of coastal communities, especially fishermen's woman.

There were several programs leaded by Universitas Diponegoro for nurturing business incubator in this program. All of those programs are focus on coastal community education and training programs for $U K M$ business incubators especially on processed food products from fisheries, starting with entrepreneurship training. Entrepreneurship training is needed to be able to change the mindset of citizens in increasing the added value of their products. One effort to increase product added value through product re-branding by promoting "contemporary" marketing. In order to make the implementation of re-branding to be more effective, social media influencers [8] were recruited from the students of Universitas. Diponegoro.

The empowerment stages that carried out were part of a model for enhancing empowerment strategies, namely: coaching, peer and modeling supervisors; and career path development and strategies [9].

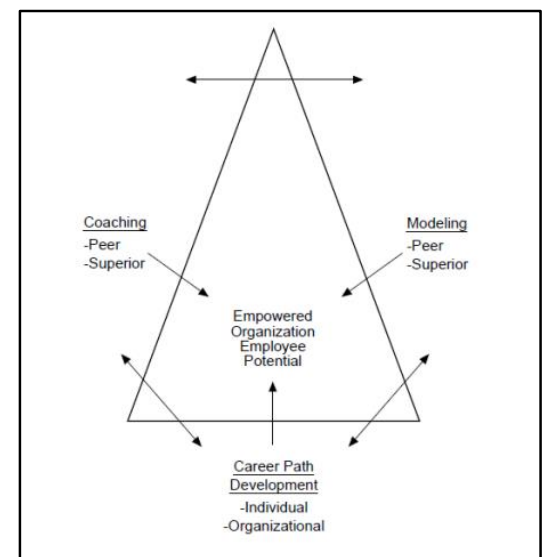

Fig. 2. Empowerment Improvement Strategy Model [9]

\section{Coaching}

Coaching is a form of mentoring that aims to improve performance through increasing capability in managing performance [10]. Coaching in empowerment is done periodically by Universitas Diponegoro through the collaboration of students-lecturers as coaches. The interesting thing is that the coach does not tell the community what to do, but improves skills and modifies behavior so that the community is able to learn, sort and choose what needs to be done. For the example is through giving motivation to the home-based processed seafood industry named "Kajiki" which is a pioneer of modern seafood processing (already having hygienic labels and packaging) in local area.

2. Modeling

Modeling is an example of effective behavior in empowerment through the formation of an ideal role that can be done by society. This can be seen from the role model of community behavior that supports and participates in community empowerment. This role model will become the differentiator because basically people will imitate what is done by people they admire or respect [11]. The Universitas Diponegoro team used a model of a successful fisherman as well as the head of the Association of Indonesian Fisherman or Himpunan Nelayan Seluruh Indonesia (HNSI) to be able to provide an overview of how real life changes. 
The wife of HNSI's head also able to establish a seafood processing business that could open jobs for other woman around that area. The selection of this model is also based on the opinion of the majority of local's people about respected figures.

\section{Career Path Development and Strategies}

Furthermore, the chosen model must also be able to meet the criteria of the "life struggle process" which will be able to become a model for the citizens. This goes along with the statement that leaders / managers get greater respect when it is known that they reach the top position with sacrifice [12]. Therefore, there are many stories of successful entrepreneurs who started from "zero", now becomes a role model for new entrepreneurs in Indonesia.

\subsection{Role of Community Development Actors}

In the practice, implementation of community development carried out by PT. Pertamina TBBM Cilacap, found a number of its own success stories. The existence of community development activities carried out by PT. Pertamina has been proven to be able to increase the degree of independency of the community in Tambakreja Urban Village, Cilacap Regency. According to our research, we have found that most people in the ring 1 area of PT. Pertamina Cilacap TBBM work as fisherman. The problem that often occurs is that most of the fishermen still have a high dependence on the presence of middlemen or tengkulak related to money for buying fisherman daily needs and fishing needs. As a result, it creates unequal exploited relationship between tengkulak and fisherman. Moreover, this relationship lowering the fish price in the market, due to oligopoly has been created by tengkulak.

Seeing these conditions, Universitas Diponegoro as an academic party, saw that there was a need for empowerment efforts carried out on these fishermen. So that the high dependency chain from fishermen to middlemen can be reduced. On the other hand, PT Pertamina TBBM Cilacap also needs to channel CSR funds in the form of empowerment. And paying attention to the needs of the community in the company's Ring 1 is a necessity and necessity.

Therefore, PT. Pertamina, collaborating with Universitas Diponegoro to create a community empowerment activity for fishermen in the Tambakreja. The result of the collaboration was the birth of a Koperasi "Mina Lumbung Jaya" (Fishermen Cooperative Firm) as an initiative to break the chain of fishermen's dependence on tengkulak. Based on the annual report issued by the Koperasi Mina Lumbung Jaya, the existence of the cooperative firm proved to be very helpful for the fishermen. At the first year, Koperasi Mina Lumbung Jaya has more than 300 fishermen members. In the future, more studies need to be done, including how the social impact of the existence of the Cooperative. However, the form of collaboration between universities (Universitas Diponegoro) and the industry sector (PT. Pertamina) and also the community (Tambakreja fishermen) is able to provide a color of its own empowerment in the midst of the community.

\section{CONCLUSION}

Based on the explanation above, it can be concluded that: community development practices need to be further improved in Indonesia, especially by prioritizing collaborative nexus approaches. This means that the role of the community is important in the effort to empower, however, the existence of academics, in this case the university is also important. And of course, the existence of the company as one of the parties that is able to provide funding support, is also very vital. By using this collaborative nexus approach, it is hoped that CSR practice will be able to create positive sum game relations between the community and 
the business sector. The role of universities in this case becomes very important as an actor who is able to become a nexus between universities, communities and businesses.

\section{References}

[1] Handayani, W., M. Sophianingrum, and U. Nutriandini, Kajian Roadmap Pengembangan Sistem Inovasi Daerah (SIDa) Kota Semarang. Riptek, 7 (2), 97-108. 2013.

[2] Angelidou, M. and A. Psaltoglou, An empirical investigation of social innovation initiatives for sustainable urban development. Sustainable Cities and Society, 2017. 33(Supplement C): p. 113125.

[3] Dunn, T., Learning to use RRA and PRA to improve the activities if two landcare groups in Australia. 1993.

[4] Creswell, J.W. and J.D. Creswell, Research design: Qualitative, quantitative, and mixed methods approaches. 2017: Sage publications.

[5] Sugiyono, M.P.K., Kualitatif, dan Kombinasi (Mixed Methods). Bandung: Alfabeta, 2013.

[6] Webster, J. and R.T. Watson, Analyzing the past to prepare for the future: Writing a literature review. MIS quarterly, 2002: p. xiii-xxiii.

[7] Etzkowitz, H. and L. Leydesdorff, The dynamics of innovation: from National Systems and "Mode 2" to a Triple Helix of university-industry-government relations. Research Policy, 2000. 29(2): p. 109-123.

[8] Freberg, K., et al., Who are the social media influencers? A study of public perceptions of personality. Public Relations Review, 2011. 37(1): p. 90-92.

[9] Geroy, G.D., P.C. Wright, and J. Anderson, Strategic performance empowerment model. Empowerment in Organizations, 1998. 6(2): p. 57-65.

[10] Cleary, M., You're the Coach: Get the most from your team with this informal-but plannedperformance management approach. Credit Union Management, 1995. 18: p. 40-40.

[11] Alder, H., A model for personal success. Management Decision, 1992. 30(3).

[12] Charter-Scott, C., The value of respect. Executive Excellence, 1997. 14(7): p. 13. 